\title{
Functional model of oxomolybdoenzymes: Synthesis and characterization of a molybdenum complex with sulphur and pterin ligands exhibiting saturation kinetics with pyridine N-oxide
}

\author{
MD AFSAR ALI and PARAG S ROY* \\ Department of Chemistry, University of North Bengal, Dist. Darjeeling \\ 734 430, India \\ e-mail: paragsroy@hotmail.com
}

MS received 30 September 2000

\begin{abstract}
Redox reaction between 6-acetonylisoxanthopterin $\left(\mathrm{H}_{2}\right.$ pte) and $\left[\mathrm{Mo}^{\mathrm{VI}} \mathrm{O}_{2}\right.$ (ssp)] [ssp = anion of 2-(salicylideneamino) benzenethiol] in $\mathrm{CH}_{3} \mathrm{OH}-\mathrm{C}_{2} \mathrm{H}_{5} \mathrm{OH}$ medium produces a new mixed ligand compound $\left[\mathrm{Mo}^{\mathrm{IV}}\right.$ (ssp) $\left.(\mathrm{Hpte})\left(\mathrm{OCH}_{3}\right)\right](\mathbf{1})$. It has been characterized by elemental analysis, ESMS data, UV-Vis, IR, ${ }^{1} \mathrm{H}$ NMR (1D and 2D) spectroscopy and cyclic voltammetry. Kinetics of formation of this compound as well as that of its reaction with pyridine N-oxide have been followed spectrophotometrically. Both the reactions follow substrate saturation kinetics and involve metal-centred oxygen atom transfer process. Large negative values of entropy of activation indicate the operation of associative mechanism.
\end{abstract}

Keywords. Mixed ligand molybdenum (IV) compound with a 6-substituted pterin; model system of oxomolybdoenzymes; oxygen atom transfer reaction.

\section{Introduction}

Recent X-ray structural characterization of several oxomolybdoenzymes reveal that a special pyranopterin (molybdopterin, chart 1) is coordinated to the molybdenum atom through a dithiolene group ${ }^{1}$. It has been proposed that the $\mathrm{Mo}(\mathrm{O})$ (molybdopterin) moiety is the metal-centred functional unit for such enzymes and variations in properties of the metal centre occur with the binding of other ligands, e.g. a terminal oxo or sulphido group, $\mathrm{OH}$ and/or $\mathrm{H}_{2} \mathrm{O}$ group(s), a second pterin, and/or a serine, a cysteine or selenocysteine group from the polypeptide backbone of the protein ${ }^{1,2}$. Such enzymes

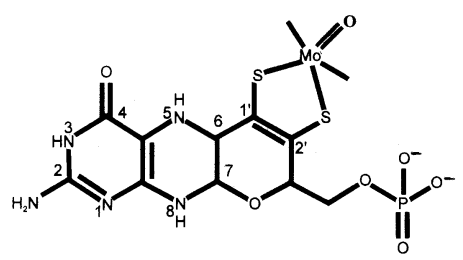

Chart 1.

\footnotetext{
*For correspondence
} 
catalyse formal hydroxylation, (1), and net oxygen atom transfer (OAT) reaction, (2), to and from a variety of biologically important substrates and the oxygen atom is ultimately derived from water ${ }^{1}$.

$$
\begin{aligned}
& \mathrm{RH}+\mathrm{H}_{2} \mathrm{O}=\mathrm{ROH}+2 \mathrm{H}^{+}+2 e^{\prime}, \\
& \mathrm{X}+\mathrm{H}_{2} \mathrm{O}=\mathrm{XO}+2 \mathrm{H}^{+}+2 e^{\prime} .
\end{aligned}
$$

Alternatively, (1) and (2) may be regarded as coupled electron-proton transfer (CEPT) reactions. Intimate catalytic mechanisms proposed for (1) and (2) involve the coordination of water to the molybdenum atom to give $\mathrm{Mo}-\mathrm{OH}_{2}, \mathrm{Mo}-\mathrm{OH}$ or $\mathrm{Mo}=\mathrm{O}$ species which cycle between the Mo(VI) and Mo(IV) oxidation states ${ }^{1(a)}$. The resolution of the X-ray crystal structures is insufficient for unambiguously resolving oxo, hydroxo and water ligands from one another, which leads to uncertainty in the oxidation state of the metal. Other limitations include uncertainty about the state of oxidation at the pyrazine ring carbon atoms, or at the side-chain sulphur-bearing carbon atoms. Hence the need for complementing the protein crystallographic results with spectroscopic data about the metal centres of these enzymes. In this context, the role of synthetic molybdenumpterin compounds is vital for recording bench-mark data; development of such coordination chemistry will also enable accomplishment of chemical and electrochemical studies that are relevant and complementary for the study of the functional aspects of the enzyme catalytic centres ${ }^{1(\mathrm{~b}), 1(\mathrm{c})}$. Besides these, considerable challenge lies ahead to achieve a clear description of how the nature of each of these metal centres changes during the operation of the enzyme's catalytic cycle as well as that of the corresponding molybdopterin moiety. For explaining the DMSO reduction capability of a synthetic Mo(IV)-pterin complex, Viscontini and co-workers ${ }^{3(\mathrm{~b}), 4,5(\mathrm{a})}$ proposed a model reaction cycle, which involves participation of the $\mathrm{NH}_{2}(2)$ and $\mathrm{NH}(5)$ protons of the pterin ring (chart 1) associated with electronic redistribution in the latter as well as in the oxo groups attached to the molybdenum centre.

In view of the above perspectives, the present work embodies the redox reaction of 6acetonylisoxanthopterin ${ }^{6}\left(\mathrm{H}_{2}\right.$ pte, whose 7 -oxo group corresponds to the pyran ring oxygen atom of molybdopterin, chart 2) with a well-established dioxomolybdenum (VI) compound $^{7},\left[\mathrm{Mo}^{\mathrm{VI}} \mathrm{O}_{2}(\mathrm{ssp})\right]$ [ssp = anion of 2-(salicylideneamino) benzenethiol], leading to the isolation of a new mixed ligand Mo(IV) compound in the solid state. Its reactivity towards pyridine $\mathrm{N}$-oxide (a typical enzyme substrate) has also been studied for corroborating the assignment of oxidation state of the metal centre ${ }^{8}$.<smiles>CC(=O)Cc1nc2c(=O)[nH]c(N)nc2[nH]c1=O</smiles>

Chart 2. 


\section{Experimental}

\subsection{Materials}

Reagent grade chemicals were used as received. Solvents were purified prior to use following the literature procedures ${ }^{9}$. Kinetic and electrochemical measurements were performed in spectroscopy grade DMF (SRL, Mumbai). 2-(Salicylideneamino) benzenethiol $\left(\mathrm{H}_{2} \mathrm{ssp}\right), \quad\left[\mathrm{Mo}^{\mathrm{VI}} \mathrm{O}_{2} \quad(\mathrm{ssp})\right]$, pyridine $\mathrm{N}$-oxide $(\mathrm{pyN} \rightarrow \mathrm{O})$ and tetrabutylammonium perchlorate (TBAP) were obtained by published methods ${ }^{7,10,11}$. 6Acetonylisoxanthopterin $\left(\mathrm{H}_{2} \mathrm{pte}\right)$ was prepared by modifying its original method of synthesis in the light of subsequent developments (e.g. darkness, $\mathrm{N}_{2}$ atmosphere, $p \mathrm{H}$ 6.4) ${ }^{6}$ and characterized through different physico-chemical methods including elemental analysis, ESMS data, 1D and 2D ${ }^{1} \mathrm{H}$ NMR spectra ${ }^{12}$.

\subsection{Synthesis of complex (1)}

The complex (1), [Mo ${ }^{\mathrm{IV}}$ (ssp) $\left.(\mathrm{Hpte})\left(\mathrm{OCH}_{3}\right)\right]$ (chart 3) was synthesized as follows. 6Acetonylisoxanthopterin $(0.235 \mathrm{~g}, 1 \mathrm{mmol})$ in methanol $(100 \mathrm{ml})$ was added to a suspension of $\left[\mathrm{Mo}^{\mathrm{VI}} \mathrm{O}_{2}(\mathrm{ssp})\right](0 \cdot 355 \mathrm{~g}, 1 \mathrm{mmol})$ in ethanol $(50 \mathrm{ml})$, and stirred for $30 \mathrm{~h}$ at room temperature $(\approx 301 \mathrm{~K})$, in darkness under dinitrogen atmosphere. The resulting chocolate-brown compound was filtered under dinitrogen using a fritte, washed with purged solvents (methanol, ether) and dried in vacuo over silica gel. Yield 50\%. Its purity was checked through TLC (silica gel $\mathrm{GF}_{254}$; UV lamp) using diluted (with 50 times methanol) DMSO solution $(\approx 0.5 \%)$ and benzene as eluant. Found: C, 47.10; H, 3.16; N, 14.52, S, 5.20\%. Calc. for $\mathrm{C}_{23} \mathrm{H}_{19} \mathrm{~N}_{6} \mathrm{O}_{5} \mathrm{~S}$ Mo: C, 46.94; H, 3.23; N, 14.29; S, 5.44\%. The $\wedge_{\mathrm{M}}\left(20 \mathrm{ohm}^{-1} \mathrm{~cm}^{2} \mathrm{~mol}^{-1}, 303 \mathrm{~K}, \mathrm{DMF}\right)$ value is consistent with its nonelectrolyte nature ${ }^{13}$. ESMS data: the peak at $\mathrm{m} / \mathrm{z}=525 \cdot 0$ (relative abundance $=100 \%$ ), associated with the characteristic distribution of molybdenum isotopes (seven) for mononuclear species, corresponds to the fragment $\left[\mathrm{M}-\mathrm{CH}_{3} \mathrm{OH}-\mathrm{CH}_{3} \mathrm{O} \text { (of 6-acetonyl substituent) }\right]^{+}$, where $\mathrm{M}$ is the molecular formula (M.W. 588) ${ }^{7(\mathrm{a}), 14,15}$. Its cyclic voltammogram is characterized by a single irreversible reduction peak [Mo (IV) $-\mathrm{Mo}$ (III)] at $-0.82 \mathrm{~V}$ $\left(50 \mathrm{mV} \mathrm{s}^{-1}\right)$; the pterin ligand $\left(\mathrm{H}_{2}\right.$ pte) itself undergoes reduction beyond $-1.8 \mathrm{~V}^{12}$. UV/Vis absorption bands [DMF, $\lambda_{\max }{ }^{n m}(\log \varepsilon): 285$ (4.23); 320 (4.16); 338 sh (4.13); 398 (3.85); $424 s h$ (3.70); 458 sh (3.46)]. ${ }^{1} \mathrm{H}$ NMR data $\left[\delta, d_{6}-\mathrm{DMSO}, 300 \mathrm{MHz}\right.$, tautomeric form of (Hpte') residue, scheme 2, involving $=\mathrm{NH}(2)$ and $\mathrm{NH}(1)$ protons]: $12.34(1 \mathrm{H}, s, \mathrm{NH}(8)), 10.96(1 \mathrm{H}, s, \mathrm{NH}(1)), 9.06(1 \mathrm{H}, s, \mathrm{CH}=\mathrm{N}), 7.84-6.89(8 \mathrm{H}, m$, protons of $\left(\mathrm{ssp}^{2-}\right)$ residue $)^{12}, 3 \cdot 74\left(2 \mathrm{H}, s, \mathrm{CH}_{2}\left(1^{\prime}\right)\right), 2 \cdot 18\left(3 \mathrm{H}, s, \mathrm{CH}_{3}\left(3^{\prime}\right)\right)$.

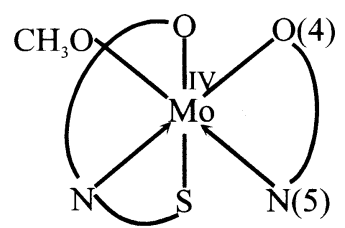

Chart 3. 


\subsection{Physical measurements and kinetic studies}

Elemental analysis $(\mathrm{C}, \mathrm{H}, \mathrm{N})$ data were obtained from the Indian Association for the Cultivation of Science, Kolkata, and sulphur was estimated by the Schöniger flask method. ${ }^{1} \mathrm{H}$ NMR data in $d_{6}$-DMSO were obtained from IICB (Bruker, DPX, $300 \mathrm{MHz}$ ), Kolkata, RSIC (Bruker, DRX, $300 \mathrm{MHz}$ ), Lucknow and TIFR (Bruker, AMX, $500 \mathrm{MHz}$ ), Mumbai. The electrospray mass spectra in methanol were obtained from RSIC (Micromass Quattro II triple quadrupole mass spectrometer), Lucknow. IR spectra on nujol mull were recorded on a Philips Analytical SP3-300 spectrometer. Electrical conductivity in DMF $0.001 \mathrm{~mol} \mathrm{dm}^{-3}$ ) was measured using a digital conductivity meter (Systronics, model 304). Cyclic voltammetry data $\left(1 \times 10^{-3} \mathrm{~mol} \mathrm{dm}^{-3}\right.$ in DMF$0.1 \mathrm{~mol} \mathrm{dm}^{-3}$ TBAP, uncorrected for the junction contribution) were recorded under purified dinitrogen atmosphere on a BAS (CV-27), USA instrument using a BAS planar platinum-inlay working electrode, a platinum-wire auxilliary electrode and a saturated calomel electrode (SCE). Electronic spectra and kinetic data (under dinitrogen atmosphere) were recorded on a Shimadzu (UV-240) spectrophotometer, with thermostatic condition $( \pm 0.5 \mathrm{~K})$ being maintained using a Shimadzu (TB-85) thermostat. Figure 1 demonstrates the absorption spectral changes associated with the reaction of $\left[\mathrm{Mo}^{\mathrm{VI}} \mathrm{O}_{2}(\mathrm{ssp})\right]$ with 6-acetonylisoxanthopterin in DMF medium at $309 \mathrm{~K}$. Kinetics of this reaction was followed at $400 \mathrm{~nm}$ and four different temperatures in the range 299-324 K under pseudo-first-order conditions (maintaining $\approx 9-109$ times excess of the pterin

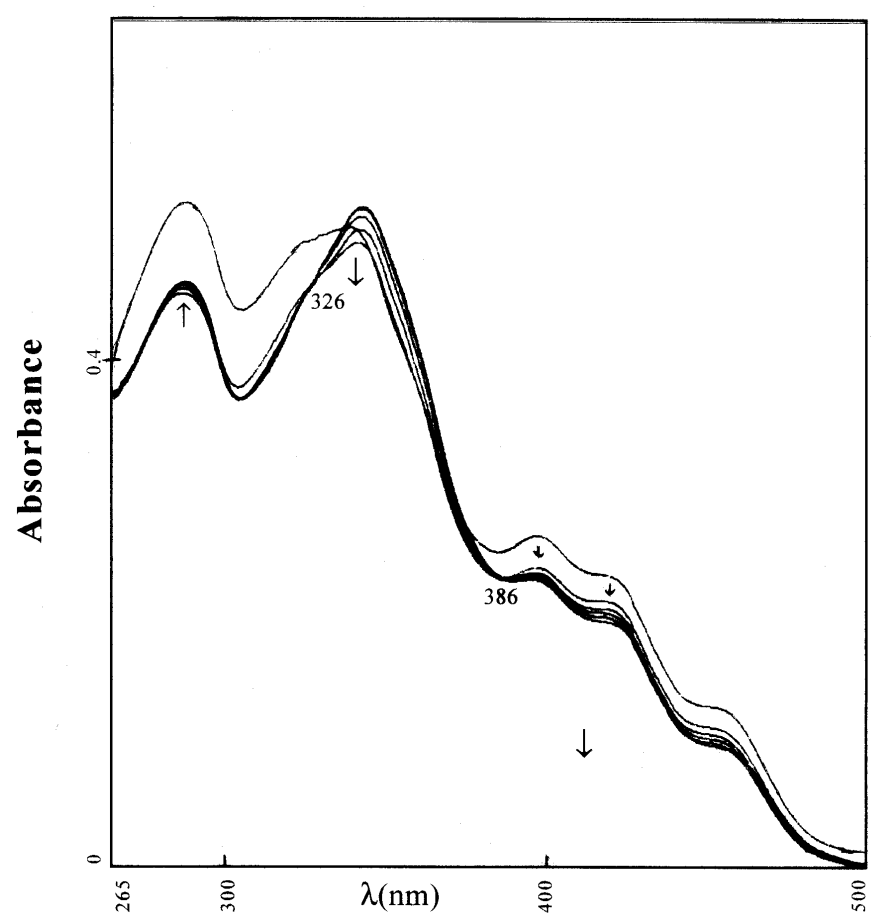

Figure 1. Absorption spectral changes recorded every 8 min during the reaction of $\left[\mathrm{Mo}^{\mathrm{VI}} \mathrm{O}_{2}(\mathrm{ssp})\right]\left(3 \times 10^{-6} \mathrm{~mol} \mathrm{dm}^{-3}\right)$ and 6-acetonylisoxanthopterin $\left(7 \times 10^{-5} \mathrm{~mol} \mathrm{dm}^{-3}\right)$ in DMF solution at $309 \mathrm{~K}$. 


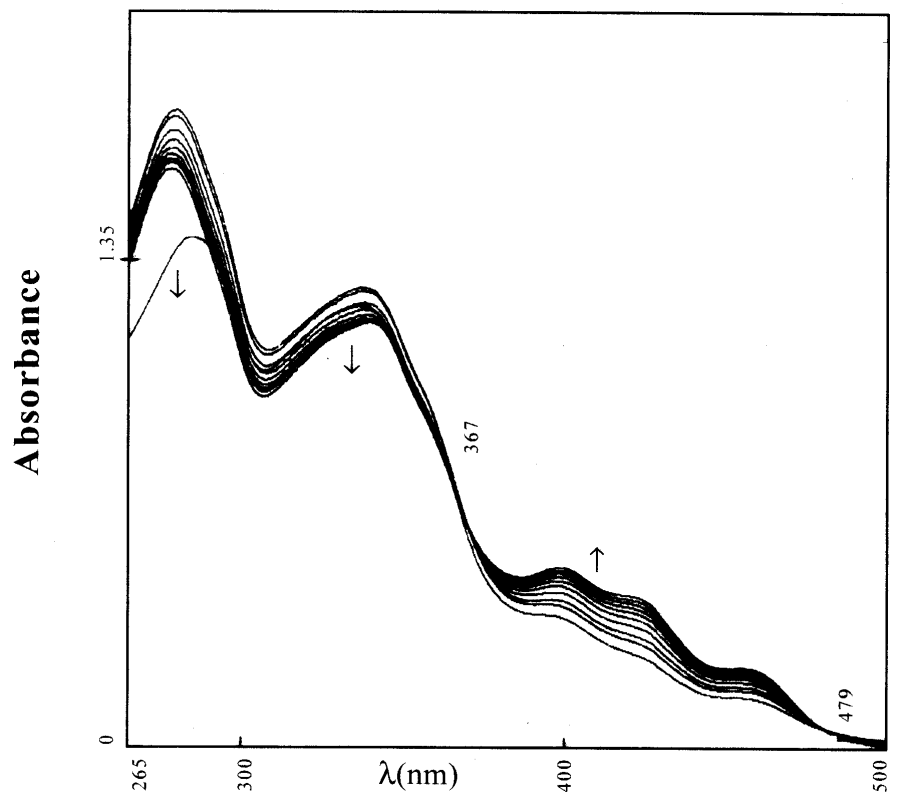

Figure 2. Absorption spectral changes recorded every $3 \mathrm{~min}$ in the reaction of $\mathbf{1}$ $\left(3.4 \times 10^{-4} \mathrm{~mol} \mathrm{dm}^{-3}\right)$ and pyridine N-oxide $\left(2.5 \times 10^{-2} \mathrm{~mol} \mathrm{dm}^{-3}\right)$ in DMF solution at $298 \mathrm{~K}$.

ligand). Observed rate constants were determined by least squares method from the plots of $\log \left(A_{\mathrm{t}}-A_{\alpha}\right)$ vs time, which were linear for at least 3 half-lives ${ }^{8}$. Figure 2 shows the course of the change in absorption spectra (DMF, $298 \mathrm{~K}$ ) over time resulting from the reaction of $\mathbf{1}$ with a typical enzyme substrate like pyridine $\mathrm{N}$-oxide ${ }^{8}$. This reaction was monitored under similar conditions as above (at $400 \mathrm{~nm}$, keeping about 13-130 fold excess of pyridine $\mathrm{N}$-oxide). As delineated later the two above-mentioned kinetic studies reflect molybdenum-centred oxygen atom transfer reactions involving two-unit reduction $[\mathrm{Mo}(\mathrm{VI}) \rightarrow \mathrm{Mo}(\mathrm{IV})]$ in the first case and subsequent reoxidation of the Mo(IV) species respectively.

\section{Results and discussion}

The ${ }^{1} \mathrm{H}$ NMR data of $\mathbf{1}$ have been assigned on the bais of the expanded spectrum $(\delta 8.0$ 6.5), the corresponding ${ }^{1} \mathrm{H}-\mathrm{H}^{1} \mathrm{COSY}$ data, protonic integration values and ${ }^{1} \mathrm{H}$ NMR data of 6-acetonylisoxanthopterin ${ }^{12}$. A tautomeric form of (Hpte') residue involving protons of the $\mathrm{N}(1)$ and $\mathrm{N}(2)$ atoms (chart 2), is consistent with these data. The $\mathrm{CH}_{3}\left(3^{\prime}\right), \mathrm{CH}_{2}\left(1^{\prime}\right)$, $\mathrm{NH}(1)$ and $\mathrm{NH}(8)$ signals of the (Hpte') residue appear as singlets at $\delta 2 \cdot 18, \delta 3 \cdot 74$, $\delta 10.96$ and $\delta 12.34$ respectively ${ }^{16}$. The characteristic azomethine $(\mathrm{CH}=\mathrm{N})$ signal at $\delta 9.06$ (singlet) of the $\left(\mathrm{ssp}^{2-}\right)$ residue is consistent with the data observed for closely related chelated ligand residues (ONO/ONS donors) in well-characterized coordination compounds of molybdenum ${ }^{7(\mathrm{a}), 17}$. The protonic integration values of these signals (e.g., $\mathrm{NH}(8)$ and $\mathrm{CH}=\mathrm{N}$ protons) indicate a 1:1 ratio of $\left(\mathrm{ssp}^{2-}\right)$ : (Hpte') in $\mathbf{1}$. The proton signal of the methoxide $\left(\mathrm{OCH}_{3}\right)$ residue is covered by the residual $\mathrm{H}_{2} \mathrm{O}$ signal (of $d_{6}$-DMSO) at $\delta 3.35$. The importance of the molybdenum-methoxide interaction has been pointed out by several authors and established through X-ray crystal structure determination in one 
case ${ }^{18}$. For 6-acetonylisoxanthopterin (in $d_{6}$-DMSO), the $\mathrm{CH}_{3}\left(3^{\prime}\right)$ and $\mathrm{CH}_{2}\left(1^{\prime}\right)$ proton signals (singlets) appear at $\delta 2.18$ and $\delta 3.74$ respectively ${ }^{12}$; in $\mathbf{1} \delta$ values of these proton signals for the (Hpte') residue remain essentially unchanged, thereby indicating that the $\mathrm{O}\left(2^{\prime}\right)$ atom of the 6-substituent (chart 2) remains uncoordinated. Besides this, the ${ }^{1} \mathrm{H}$ NMR data of 6-acetonylisoxanthopterin also indicate that the $\mathrm{NH}_{2}(2)$ group exists here as shown in chart 2 , with its two protons appearing essentially as a broad signal at $\delta 7 \cdot 0$. However, during the redox reaction of $\mathrm{H}_{2}$ pte with $\left[\mathrm{Mo}^{\mathrm{VI}} \mathrm{O}_{2}(\mathrm{ssp})\right]$, a tautomeric change takes place and the $\mathrm{NH}(1)$ signal appears at $\delta 10.96$ in $\mathbf{1}$; this supports the participation of the pterin ring during oxygen atom transfer reaction occurring at the molybdenum centre $(\text { chart } 3)^{3(b)}$. The $=\mathrm{NH}(2)$ proton signal $(\mathbf{1})$ lies hidden under proton signals of the $\left(\mathrm{ssp}^{2-}\right)$ residue, as evident from protonic integration data of the expanded spectrum $(\delta 8 \cdot 0-6 \cdot 5){ }^{12}$.

A comparative study of the IR spectra of $\mathbf{1}$ and the reactants responsible for its formation, throws light on the nature of the ligand (Hpte') donor atoms as well as on the molybdenum-centred oxygen atom transfers occurring during its formation. IR absorptions typical of terminal $\mathrm{Mo}=\mathrm{O}\left(930 \mathrm{~cm}^{-1}\right)$ and bridging $\mathrm{Mo}=\mathrm{O} \rightarrow \mathrm{Mo}\left(780 \mathrm{~cm}^{-1}\right)$ groups of $\left[\mathrm{Mo}^{\mathrm{VI}} \mathrm{O}_{2}\right.$ (ssp)] are absent in case of $\mathbf{1}^{7(\mathrm{~b}), 17}$, indicating removal of such molybdenum-oxygen entities through reaction with the redox noninnocent pterin ligand. The residual IR band at $780 \mathrm{~cm}^{-1}$ of $\mathbf{1}$ can be correlated with the IR absorption of the $\left(\mathrm{ssp}^{2-}\right)$ residue, as verified through recording of IR spectrum of $\mathrm{H}_{2} \mathrm{ssp}^{7(\mathrm{a})}$. The intense IR bands in the region $1700-1600 \mathrm{~cm}^{-1}$ of $\mathrm{H}_{2}$ pte are modified significantly on coordination to the molybdenum atom in $\mathbf{1}$, reflecting enolisation of the 4-oxo group followed by coordination of the (Hpte') residue involving the $\mathrm{O}(4), \mathrm{N}(5)$ atoms, where the Mo-N(5) bond plays a pivotal role ${ }^{3(\mathrm{~b}), 5,19}$. The $\mathrm{v}(\mathrm{C}=\mathrm{O})$ modes of the $2^{\prime}$ and 7-oxo groups appear together at $1625 \mathrm{~cm}^{-1}$ as a strong broad band in $\mathbf{1}$; the $\mathrm{v}(\mathrm{CH}=\mathrm{N})$ mode of the azomethine group (observed at $1598 \mathrm{~cm}^{-1}$ in $\left[\mathrm{Mo}^{\mathrm{VI}} \mathrm{O}_{2}(\mathrm{ssp})\right]$ and the $\mathrm{v}(\mathrm{C}=\mathrm{C}), \mathrm{v}(\mathrm{C}=\mathrm{N})$ vibrations of the pterin ring lie hidden under this band ${ }^{5}$. Now considering the tridentate ONS donating $\left(\mathrm{ssp}^{2-}\right)$ residue and the $\left(\mathrm{OCH}_{3}\right)$ group, a coordination number of 6 can be inferred for the Mo(IV) atom in 1 (chart 3) ${ }^{7(a), 18(a)}$.

Reactivity (discussed later) of $\mathbf{1}$ towards pyridine $\mathrm{N}$-oxide indicates that the molybdenum atom exists here in a lower oxidation state, e.g. +4 . The relevant oxidation product was isolated by reacting ( $328 \mathrm{~K}$, darkness, $5 \mathrm{~h}$, DMF) 1 with pyridine $\mathrm{N}$-oxide (in 1:3 molar ratio), followed by evaporation in a rotary evaporator, treatment of the residue with methanol, filtration and washing with ether; elemental analysis indicated the composition $\left[\mathrm{Mo}_{2}{ }^{\mathrm{VI}} \mathrm{O}_{5}(\mathrm{Hssp})(\mathrm{Hpte})\right.$ ]. 0.5 DMF. The $\mathrm{v}(\mathrm{Mo}=\mathrm{O})$ and $\mathrm{v}(\mathrm{Mo}-\mathrm{O}-\mathrm{Mo})$ modes characteristic of the $\left[\mathrm{Mo}_{2}{ }^{\mathrm{VI}} \mathrm{O}_{5}{ }^{2+}\right]$ core are observed at $925,888 \mathrm{~cm}^{-1}$ and $825 \mathrm{~cm}^{-1}$ respectively ${ }^{20}$. Most likely the initial product (e.g., possessing the $\left[\mathrm{Mo}^{\mathrm{VI}} \mathrm{O}^{4+}\right]$ core) of pyridine N-oxide oxidation undergoes hydrolysis with the moisture present in the solvents and $\mu$-oxo dimerization reaction, giving ultimately the $\mathrm{Mo}_{2}{ }^{\mathrm{VI}} \mathrm{O}_{5}{ }^{2+}$ species $[5(\mathrm{a})-$ $5(\mathrm{c})]^{19,20(\mathrm{c}, \mathrm{d})}$.

Figures 1 and 2 represent the spectrophotometric monitoring of the reaction of $\left[\mathrm{Mo}^{\mathrm{VI}} \mathrm{O}_{2}(\mathrm{ssp})\right]$ with $\mathrm{H}_{2}$ pte and that of $\mathbf{1}$ with pyridine $\mathrm{N}$-oxide respectively ${ }^{21(\mathrm{a}) \text {,(b) }}$. In figure 1 isobestic points are observed at 326 and $386 \mathrm{~nm}$, while two isobestic points can be identified at 367 and $479 \mathrm{~nm}$ in figure 2. Both the reaction systems exhibit saturation kinetics at sufficiently high substrate concentration (figures 3 and 4$)^{21}$. Under these conditions, the reactions are first order in $\left[\mathrm{Mo}^{\mathrm{VI}} \mathrm{O}_{2}(\mathrm{ssp})\right]$ and 1 respectively, as shown by linear plots of $\log \left(A_{t}-A_{\alpha}\right)$ vs time, from which the observed rate constants were obtained $^{8(\mathrm{a}), 8(\mathrm{c}), 17,23}$. 


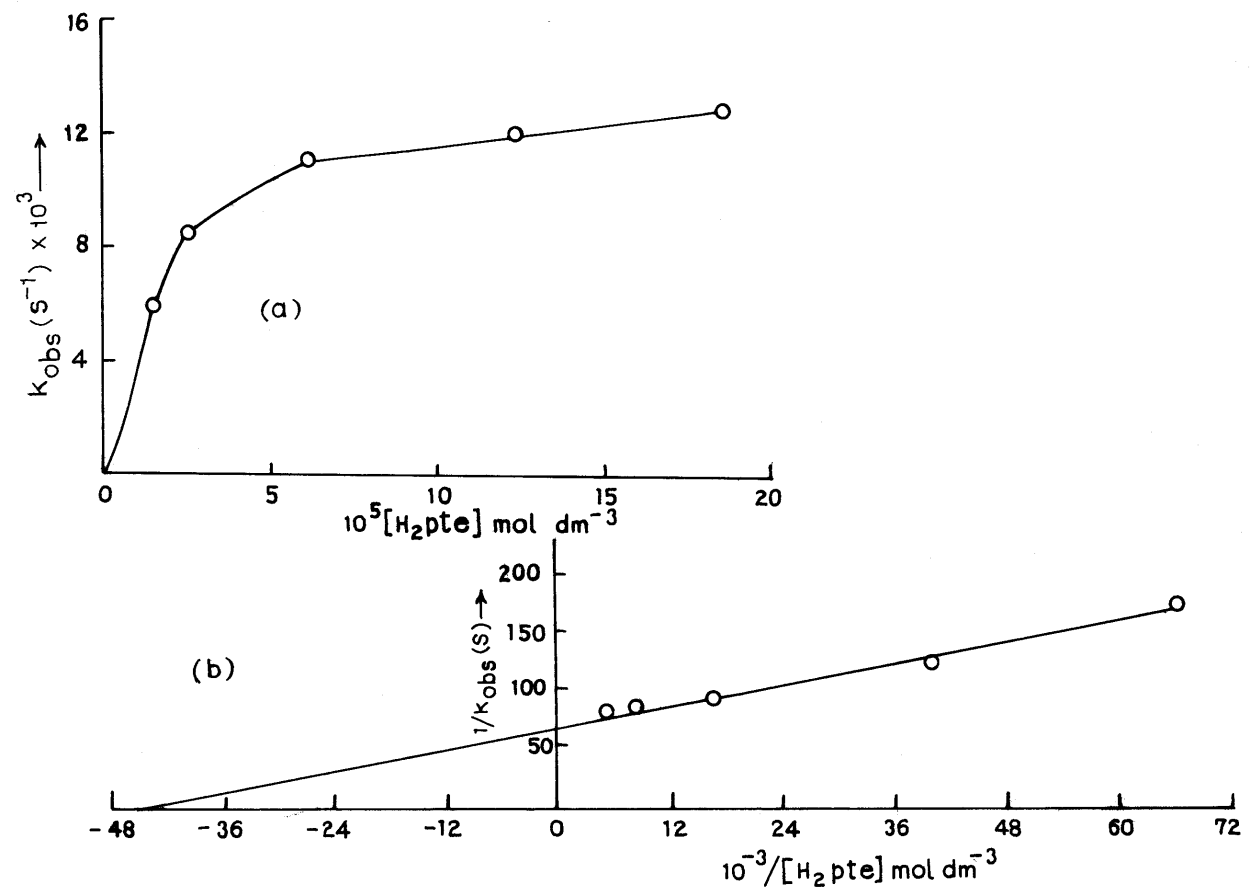

Figure 3. (a) Dependence of the rate of reaction of $\left[\mathrm{Mo}^{\mathrm{VI}} \mathrm{O}_{2}(\mathrm{ssp})\right](1.7 \times$ $10^{-6} \mathrm{~mol} \mathrm{dm}^{-3}$ ) and 8.8-108.8 equivalent of $\mathrm{H}_{2}$ pte in DMF at $299 \mathrm{~K}$ on $\mathrm{H}_{2}$ pte; (b) the corresponding double reciprocal plot.

The reaction (scheme 1) leading to the formation of 1, i.e. the Mo (IV) mixed ligand compound, is initiated through reversible substrate $[\mathrm{S}]$, i.e., $\left(\mathrm{H}_{2} \mathrm{pte}\right)$ binding, followed by oxo transfer (along wtih coupled $\mathrm{H}^{+} / e^{\prime}$ transfer) with rate constant $k_{2}$. During isolation of the product on preparative scale in presence of methanol, further reactions occur with loss of both the oxo groups of $\left[\mathrm{Mo}^{\mathrm{VI}} \mathrm{O}_{2}\right.$ (ssp)], giving 1 as the ultimate product (vide 2 ). Loss of oxo ligands, during complex formation process involving $\mathrm{Mo}^{\mathrm{VI}} \mathrm{O}_{2}{ }^{2+}$ starting materials, is rare with conventional ligands unless an oxo abstractor like $\mathrm{PPh}_{3} / \mathrm{Ph}_{2} \mathrm{MeP}$ is present $^{7(\mathrm{a}),(\mathrm{c}), 17,23(\mathrm{a})}$. In terms of scheme 1 the observed rate constant $\left(k_{\mathrm{obs}}\right)$ can be represented as follows ${ }^{22}$ :

$$
k_{\mathrm{obs}}=\left(k_{2}[\mathrm{~S}] /\left(K_{m}+[\mathrm{S}]\right),\right.
$$

where $K_{m}=\left(k_{2}+k_{-1}\right) / k_{1}$ or

$$
\frac{1}{k_{\mathrm{obs}}}=\frac{1}{k_{2}}+\frac{K_{m}}{k_{2}[\mathrm{~S}]} .
$$

A plot of the observed rate constant $\left(k_{\mathrm{obs}}\right)$ vs $\left[\mathrm{H}_{2}\right.$ pte] is shown in figure $3 \mathrm{a}$. The plot of $1 / k_{\text {obs }}$ vs $1 /\left[\mathrm{H}_{2}\right.$ pte] should give a straight line with $1 / k_{2}$ as the intercept and $K_{m} / k_{2}$ as the slope. The $x$-axis intercept equals $1 / K_{m}$. From the double reciprocal plot of $1 / k_{\text {obs }}$ vs $1 /\left[\mathrm{H}_{2}\right.$ pte] (figure 3b), $k_{2}$ and $K_{m}$ were calculated as $1.5 \times 10^{-2} \mathrm{~s}^{-1}$ and $2 \cdot 2 \times 10^{-5} \mathrm{~mol} \mathrm{dm}^{-3}$ 


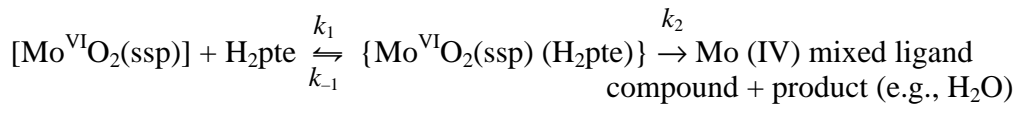

Scheme 1.

$$
\text { Compound } 1+\text { pyN } \rightarrow \mathrm{O} \underset{k_{-1}}{\stackrel{k_{1}}{\leftrightharpoons}}\left\{\text { compound } 1\left(\text { pyN } \stackrel{k_{2}}{\rightarrow} \mathrm{O}\right)\right\} \rightarrow \mathrm{Mo}(\mathrm{VI}) \text { mixed ligand }
$$

Scheme 2.

respectively at $299 \mathrm{~K}$. The value of $k_{2}$ is comparable in magnitude to those of molybdenum-mediated oxygen atom transfer reactions obtained using a wide variety of model compounds and substrates ${ }^{8,17,23}$. Activation parameters $\left[\Delta H^{\ddagger}=11.3 \mathrm{~kJ} \mathrm{~mol}^{-1}\right.$; $\left.\Delta S^{\ddagger}=-200.8 \mathrm{~J} \mathrm{~K}^{-1} \mathrm{~mol}^{-1}\right]$ were obtained from the Eying plot $[\ln (k / T)$ vs $1 / T]$ using pseudo-first-order rate constants data determined (keeping a 90-fold excess of $\mathrm{H}_{2}$ pte) at different temperatures. The negative activation entropy is consistent with the proposed associative mechanism (scheme 1) ${ }^{24}$.

Scheme 2 represents the possible pathway of the reaction between 1 and pyridine $\mathrm{N}$ oxide in DMF medium, which involves the reversible formation of an intermediate involving both the reactants, followed by its transformation to the products. Reaction stoichiometry was established by estimating the amount of pyridine released through the reaction $\left(328 \mathrm{~K}, 50 \mathrm{~h}, \mathrm{~N}_{2}\right.$ atm, darkness) of a known weight of 1 with 10 equivalents of pyN $\rightarrow \mathrm{O}$; pyridine was determined gravimetrically as the known compound $\left[\mathrm{Zn}\left(\mathrm{C}_{5} \mathrm{H}_{5} \mathrm{~N}\right)_{2}\right](\mathrm{SCN})_{2}$ from the petroleum ether extract of the reaction medium ${ }^{25}$. About 2 mols of pyridine were recovered per mol of $\mathbf{1}$ added as per the following equations.

$$
\begin{aligned}
& 2(\mathbf{1})+2 \text { py } \mathrm{N} \rightarrow \mathrm{O} \rightarrow 2\left[\mathrm{Mo}^{\mathrm{VI}} \mathrm{O}^{4+}\right] \text { complex }+2 \text { py, } \\
& 2\left[\mathrm{Mo}^{\mathrm{VI}} \mathrm{O}^{4+}\right] \text { complex }+2 \text { pyN } \rightarrow \mathrm{O}+\mathrm{H}_{2} \mathrm{O} \rightarrow \\
& {\left[\mathrm{Mo}_{2}{ }^{\mathrm{VI}} \mathrm{O}_{5}{ }^{2+}\right] \text { complex }+2 \mathrm{py}+2 \mathrm{H}^{+} \text {, }} \\
& 2(\mathbf{1})+4 \mathrm{pyN} \rightarrow \mathrm{O}+\mathrm{H}_{2} \mathrm{O} \rightarrow\left[\mathrm{Mo}_{2}{ }^{\mathrm{VI}} \mathrm{O}_{5}{ }^{2+}\right] \text { complex }+4 \mathrm{py}+2 \mathrm{H}^{+} .
\end{aligned}
$$

The plot of observed rate constant $\left(k_{\mathrm{obs}}\right)$ vs [py $\mathrm{N} \rightarrow \mathrm{O}$ ] is shown in figure 4a. Assuming the validity of (3) and (4) in this case as well, the double reciprocal plot of $1 / k_{\text {obs }}$ vs $1 /[$ py $\mathrm{N} \rightarrow \mathrm{O}]$ (figure 4b) was utilized for the calculations of $k_{2}=6.7 \times 10^{-2} \mathrm{~s}^{-1}$ and $K_{m}=$ $2.3 \times 10^{-3} \mathrm{~mol} \mathrm{dm}^{-3}$ at $299 \mathrm{~K}$. Variable temperature pseudo-first-order rate constants data (determined using 80 -fold excess of pyN $\rightarrow \mathrm{O}$ ) were used for calculating the activation parameters $\left(\Delta H^{\star}=3.8 \mathrm{~kJ} \mathrm{~mol}^{-1} ; \Delta S^{\ddagger}=-200 \cdot 3 \mathrm{JK}^{-1} \mathrm{~mol}^{-1}\right)$ from the Eyring plot. The negative $\Delta S^{\ddagger}$ value supports the formation of an intermediate in scheme 2 . The $k_{2}$ value is in line with the existing rate constants data for oxo transfer reactions of various Mo(IV) complexes with pyridine $\mathrm{N}$-oxide and other similar substrates ${ }^{8(\mathrm{c}), 23(\mathrm{~b})}$. 

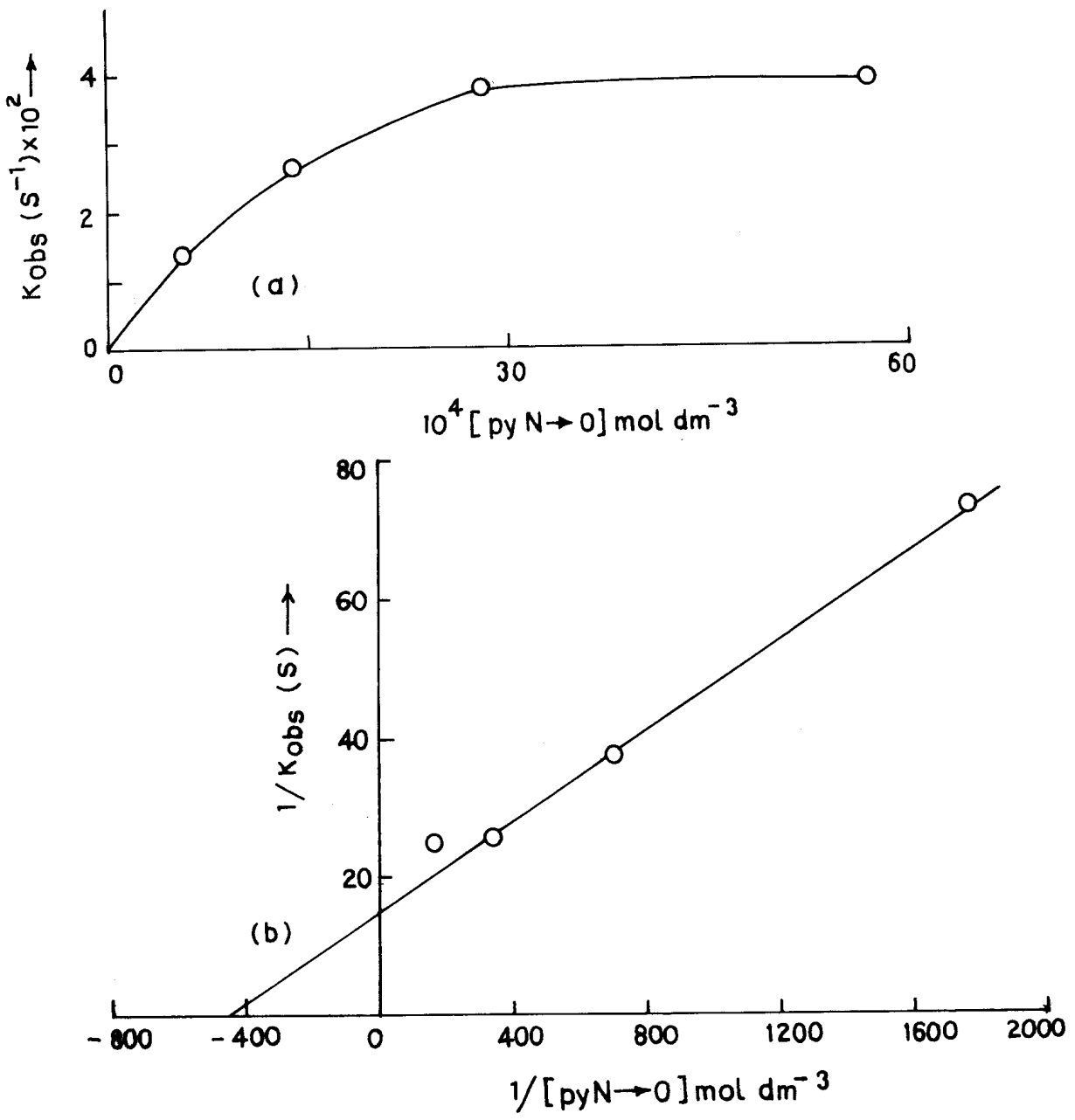

Figure 4. (a) Dependence of the rate of reaction of $1\left(4.4 \times 10^{-5} \mathrm{~mol} \mathrm{dm}^{-3}\right)$ and $12 \cdot 9-129 \cdot 2$ equivalent of py $\mathrm{N} \rightarrow \mathrm{O}$ in $\mathrm{DMF}$ at $299 \mathrm{~K}$ on $\mathrm{pyN} \rightarrow \mathrm{O}$; (b) the corresponding double reciprocal plot.

\section{Conclusions}

${ }^{1} \mathrm{H}$ NMR and IR spectral data point out that $\mathrm{H}_{2}$ pte exhibits redox noninnocent behaviour during its reaction with $\left[\mathrm{Mo}^{\mathrm{VI}} \mathrm{O}_{2}\right.$ (ssp)]; the loss of oxygen atoms of the latter (leading to the formation of $\mathbf{1}$ ) is accompanied by a tautomeric change involving the $\mathrm{NH}_{2}(2)$ group (chart 2) and related electronic redistribution in the pterin ring. The process is characterized by substrate saturation kinetics (figure 3) and may be regarded as a CEPT reaction. On the other hand, the reaction between $\mathbf{1}$ and pyridine $\mathrm{N}$-oxide is essentially an OAT process, conforming to substrate saturation kinetics as well (figure 4) and throwing light on the oxidation state of the molybdenum atom in $\mathbf{1}$. The final product in $(5 \mathrm{c})$ reflects the role of hydrolysis and $\mu$-oxo dimerization reaction. The reductive half 
reaction of xanthine oxidase with substoichiometric amounts of xanthine exhibits substrate saturation kinetics with faster $k_{2}$ values ${ }^{21(\mathrm{c})}$.

Finally, the role of the solvent used for the preparative purpose here (e.g., $\mathrm{CH}_{3} \mathrm{OH}$ ) is to be assessed vis-a-vis that of $\mathrm{H}_{2} \mathrm{O}$ in the catalytic cycle of oxomolybdoenzymes. As pointed out in the introductory part, loss of an oxo group from the Mo(VI) species during enzyme turnover is made up by the $\mathrm{H}_{2} \mathrm{O}$ molecule giving $\mathrm{Mo}-\mathrm{OH}_{2}$ and undergoes facile deprotonation to $\mathrm{Mo}-\mathrm{OH}$ or $\mathrm{Mo}=\mathrm{O}$ species accompanied by changes in oxidation state of the metal centre ${ }^{1(\mathrm{a}), 26}$. During formation of $\mathbf{1}$, loss of oxo groups from $\left[\mathrm{Mo}^{\mathrm{VI}} \mathrm{O}_{2}\right.$ (ssp)] is made up partly by the pterin ligand residue $\left(\mathrm{Hpte}^{2}\right)^{2(\mathrm{a})}$ and partly by the solvent molecule $\left(\mathrm{CH}_{3} \mathrm{OH}\right)$; charge balance is achieved through deprotonation leading to methoxide group formation $^{18}$.

\section{Acknowledgements}

The authors express their gratitude to the CSIR, New Delhi, for a research fellowship (to MAA), the Department of Science and Technology and University Grants Commission, New Delhi for financial support (to PSR), Indian Association for the Cultivation of Science, Kolkata for microanalytical data, RSIC, CDRI, Lucknow for ESMS and NMR spectra. Some of the NMR spectra were recorded by TIFR, Mumbai and IICB, Kolkata.

\section{References}

1. (a). McMaster J and Enemark J H 1998 Curr. Opinion Chem. Biol. 2 201; (b) Enemark J H and Garner C D 1997 J. Biol. Inorg. Chem. 2 817; (c) Collison D, Garner C D and Joule J A 1996 Chem. Soc. Rev. 2525

2. Stiefel E I 1996 Science 2721599

3. (a) Fischer B, Schmalle H W, Baumgartner M R and Viscontini M 1997 Helv. Chim. Acta 80 103; (b) Fischer B, Schmalle H, Dubler E, Schafer A and Viscontini M 1995 Inorg. Chem. 34 5726; (c) Fischer B, Strahle J and Viscontini M 1991 Helv. Chim. Acta 741544

4. Kaim W 1987 Rev. Chem. Intermediates 8247

5. (a) Perkinson J, Brodie S, Yoon K, Mosny K, Carroll P J, Morgan T V and Burgmayer S J N 1991 Inorg. Chem. 30 719; (b) Burgmayer S J N and Stiefel E I 1988 Inorg. Chem. 274059

6. (a) Matsuura S, Nawa S, Kakizawa H and Hirata Y 1953 J. Am. Chem. Soc. 75 4446; (b) Korte F and Wallace R 1964 Pteridine chemistry (eds) W Pfleiderer and E C Taylor (Oxford: Pergamon) pp. 75-86; (c) Schircks B, Bieri J H and Viscontini M 1985 Helv. Chim. Acta 68 1639; (d) Russell J R, Garner C D and Joule J A 1992 Synlett. 711

7. (a) Craig J A, Harlan E W, Snyder B S, Whitener M A and Holm R H 1989 Inorg. Chem. 28 2082; (b) Rajan O A and Chakravorty A 1981 Inorg. Chem. 20 660; (c) Boyd I W and Spence J T 1982 Inorg. Chem. 211602

8. (a) Holm R H 1990 Coord. Chem. Rev. 100 183; (b) Craig J A and Holm R H 1989 J. Am. Chem. Soc. 111 2111; (c) Schultz B E and Holm R H 1993 Inorg. Chem. 32 4244; (c) Holm R H and Berg J M 1984 Pure Appl. Chem. 561645

9. (a) Vogel A I 1978 Textbook of practical organic chemistry 4th edn (London: Longman/ ELBS) chap 2; (b) Perrin D D and Armarego W L F 1988 Purification of laboratory chemicals 3rd edn (Oxford: Pergamon)

10. (a) Bellas M and Suschitzky H 1963 J. Chem. Soc. 4007; (b) Carde R N, Hayes P C, Jones G and Cliff C J 1981 J. Chem. Soc., Perkin Trans. 11132

11. Sawyer D T and Roberts J L Jr. 1974 Experimental electrochemistry for chemists (New York: Wiley) p. 212

12. Supplementary data available with the authors include ESMS, IR, ${ }^{1} \mathrm{H}$ NMR (1D and 2D) and $\mathrm{CV}$ data of $\mathrm{H}_{2}$ pte and 1; expanded NMR (1D and 2D) data identify each proton signal of $\left(\mathrm{ssp}^{2-}\right)$ residue in $\mathbf{1}$. 
13. Geary W J 1971 Coord. Chem. Rev. 7110

14. Ebsworth E A V, Rankin D W H and Cradock S 1987 Structural methods in inorganic chemistry (Oxford: Blackwell/ELBS) p. 349

15. Young C G 1995 J. Chem. Edu. 72 751, and the additional information folder available with the author

16. (a) Soyka R, Pfleiderer W and Prewo R 1990 Helv. Chim. Acta 73 808; (b) Soyka R and Pfleiderer W 1990 Pteridines 263

17. (a) Bhattacharjee S and Bhattacharyya R G 1992 J. Chem. Soc., Dalton Trans. 1357; (b) Bhattacharjee S and Bhattacharyya R G 1993 J. Chem. Soc., Dalton Trans. 1151

18. (a) Gibson V C, Redshaw C, Walker G L P, Howard J A K, Hoy V J, Cole J M, Kuzmina L G and De Silva D S 1999 J. Chem. Soc., Dalton Trans. 161; (b) Bazhenova T A, Bazhenova M A, Petrova G N, Shilova A K and Shilov A E 1998 Russ. Chem. Bull. 47861

19. Stiefel E I 1977 Prog. Inorg. Chem. 221

20. (a) Burgmayer S J N, Arkin M R, Bostick L, Dempster S, Everett K M, Layton H L, Paul K E, Rogge C and Rheingold A L 1995 J. Am. Chem. Soc. 117 5812; (b) Kaufmann H L, Sands L L, Rheingold A L and Burgmayer S J N 1999 Inorg. Chem. 38 2592; (c) Kaufmann H L, Carroll P J and Burgmayer S J N 1999 Inorg. Chem. 38 2600; (d) Burgmayer S J N, Kaufmann H L, Fortunato G, Hug P and Fischer B 1999 Inorg. Chem. 382607

21. (a) Bastian N R, Kay C J, Barber M J and Rajagopalan K V 1991 J. Biol. Chem. 266 45; (b) Wuebbens M M and Rajagopalan K V 1993 J. Biol. Chem. 268 13493; (c) Kim J H and Hille R 1993 J. Biol. Chem. 26844

22. (a) Ochiai E I 1977 Bioinorganic chemistry (Boston: Allyn and Bacon) p. 27; (b) Das S K, Chaudhury P K, Biswas D and Sarkar S 1994 J. Am. Chem. Soc. 1169061

23. (a) Berg J M and Holm R H 1985 J. Am. Chem. Soc. 107 917, 925; (b) Caredonna J P, Reddy P R and Holm R H, 1988 J. Am. Chem. Soc. 110 2139; (c) Craig J A and Holm R H 1989 J. Am. Chem. Soc. 1112111

24. Wilkins R G 1991 Kinetics and mechanism of reactions of transition metal complexes 2nd edn (Weinheim: VCH) pp 87, 105

25. Vogel A I 1978 Textbook of quantitative inorganic analysis 4th edn (England: Longman/ ELBS) p. 489

26. Enemark J H and Young C G 1993 Adv. Inorg. Chem. 401 